\title{
Collateral quality and loan default risk: the case of Vietnam
}

Chau H.A Le \& Hieu L. Nguyenb $^{b}$

a Chau H.A. Le (haulha@ueh.edu.vn), School of Banking, University of Economics HCMC, 59C Nguyen Dinh Chieu, Dist. 3, Ho Chi Minh City, Vietnam.

b Hieu L. Nguyen (hieu.nl@vnp.edu.vn), The Vietnam - Netherlands Programme (VNP), University of Economics HCMC, 1A Hoang Dieu, Phu Nhuan Dist., Ho Chi Minh City, Vietnam.

Abstract: In the transition economy of Vietnam, financial market is dominated by banking sector but commercial banks heavily rely on collateral-based lending. While the relationship between collateral and implied credit risk is still in debate, this paper provides additional empirical evidence regarding the heterogeneous effects and transmission channels of collateral characteristics on loan delinquency. Applying instrumental variable probit analysis on a unique dataset of 2,295 internal loan accounts in Vietnam, we find the significantly negative impact of collateral quality on the probability of default of consumer loans, supporting the dominance of borrower selection and risk-shifting over lender selection effects. The finding implies that high quality collateral not only signals more credible borrower but also fosters good behavior in using loan, enabling bank to mitigate adverse selection and moral hazard problems.

Keywords: bank loan, collateral-based lending, collateral characteristics, risk-shifting effect, probability of default, Vietnam

JEL Classification: G20, G21, C18 


\section{Introduction}

Lending in low income countries is notoriously risky because of the information asymmetry problems which are potentially higher than that of developed countries (Menkhoff, Neuberger, \& Suwanaporn, 2006). Therefore, collateral has been widely used as a mechanism to reduce equilibrium credit rationing and the asymmetric information between borrowers and lenders (Haselmann \& Wachtel, 2007). Theoretical frameworks focus on the different channels that predict the role of collateral in bank lending and credit risk. For example, theories relating to ex post contracting frictions (Stiglitz \& Weiss, 1981) explain the positive relation between collateral and loan risk with the lender selection effect. Alternatively, negative effects of collateral can be explained by a borrower selection effect (an ex-ante theory) or by the dominance of risk-shifting and loss-mitigating effects in ex-post theories (Berger, Frame, \& Ioannidou, 2016). Empirical studies provide even more diversified evidence about this relationship, resulting in conflicting implications and challenges for policy makers. Berger et al. (2016) argue that the strength of each channel is not only dependent on whether loans are protected by collateral, but also on the characteristics of loans and types of collateral.

We revisit this puzzle in the context of a transition economy, Vietnam, where the banking sector is heavily reliant on collateral-based lending and where credit risk has always been a major concern. Non-performing loans (NPLs) increased sharply after 2011 and remain serious despite the State Bank of Vietnam's (SBV) strong efforts in bank restructuring and bad debt resolution. Loans in the Vietnamese banking sector are primarily secured loans; therefore, collateral plays an essential role in the control of NPLs. Although Vietnamese banks insist that lending decisions are based on their assessment of borrowers' payment ability, in practice, collateral is the most important consideration in the decision to approve a loan. Banks always request highly liquid 
collateral from risky borrowers to reduce moral hazard and other ex post frictions and protect themselves from loan risks. However, anecdotal evidence shows that heavy reliance on collateral may lead to negligence in screening and monitoring processes; consequently, leading to substantial increases in bad debt. Since the process of collateralized property foreclosure is costly and time-consuming, banks' loss recovery from collateral liquidation has been considered uncertain and unpromising. A different view is that collateral is usually a valuable asset in a low-income country like Vietnam. Therefore, people tend to make an effort to prevent their asset losses, especially in the case of highly desirable collateral. While role of collateral is still debated in the literature and practice, empirical studies linking loan risk and collateral in Vietnam may provide useful policy implication for bank managers and SBV authorities.

This study uses a unique data set of 2,295 credit files from the internal loan accounts of a Vietnamese commercial bank to examine the impact of collateral characteristics on a loan's probability of default (PD) and the implicit transmission channels. We contribute to contemporary literature in many aspects. First, we provide additional empirical evidence regarding the role of collateral in lending markets where there exists serious information asymmetry associated with weak credit risk management, a complex and restrictive regulatory framework and an underdeveloped financial infrastructure. Second, this study focuses on consumer loans instead of commercial loans and investigates the variation in PD of fully collateralized loans rather than comparing secured and non-secured loans. Third, the findings from this study lend support to Berger et al. (2016) in explaining different risk-collateral relations implied by economic theory. The identification of specific risk-shifting and borrower selection channels suggests effective policy intervention for both credit risk resolution and financial inclusion enhancement in this transition economy. 


\section{Literature Review on the Relationship Between Collateral Pledging and Loan}

\section{Risk}

There are two strands of theories that explain different effects of collateral on loan risk. The ex ante theories suggest that good borrowers are willing to pledge more and desirable collateral to signal their underlying quality and get lower risk premiums. They choose to pledge collateral in order to avoid screening cost of banks (Bester, 1985). Pagano, Manove, and Padilla (2001) argue that in equilibrium, banks screen all projects, but fund the good ones only and charge an interest rate which is equal to the cost of funds plus the screening cost of that approved project and the prorated share of the screening cost of all unapproved projects. Banks tend to loosen the screening process if they are highly protected by collateral. Hence, a negative relation between collateral pledging and credit risk is a consequence of a borrower selection effect. However, the collateral-risk relation can be also analyzed from the ex post point of view via lender selection, risk shifting and loss mitigation effects. The lender selection effect implies that collateral is a part of optimal risk contract as banks require low quality borrowers/projects to pledge collateral to reduce moral hazard and other ex post frictions and protect themselves from loan risks (Stiglitz \& Weiss, 1981). The riskshifting effect comes from the borrowers' motivation to shift into a safer investment portfolio to avoid asset loss, whereas the loss mitigation effect is that collateral pledges reduce losses for the lender in the event of borrower default.

Voluminous empirical studies have tested the risk-collateral relation, but the findings are even more conflicting. Berger and Udell (1990) examine the role of collateral in explaining credit risk of 460 US banks and find that collateral is most often associated with riskier borrowers; hence riskier loans and banks. This confirms conventional wisdom in the banking community that banks require higher risk- 
borrowers to pledge collaterals to avoid credit frictions. This positive relationship between collateral and default risk has been supported by vast number of studies across countries (Brick \& Palia, 2007; Godlewski \& Weill, 2011; Џiménez \& Saurina, 2004; Џohn, Lynch, \& Puri, 2003; Machauer \& Weber, 1998), suggesting the dominance of lender selection explained by ex post theories.

However, the literature on relationship lending shows that the role of pledged collateral depends on the proximity between bank and borrower (Cerqueiro, Ongena, \& Roszbach, 2016). The effect of collateral in different lending relationships has been investigated. Degryse and Van Cayseele (2000) find that the risk premium is lower in collateralized loans, implying that banks use collateral to solve the problem of hidden information in designing optimal debt contracts, i.e. collateralized loans have a lower interest rate and non-collateralized loans a higher rate. Voordeckers and Steijvers (2006) provide evidence of the negative relationship between collateral and risk in Belgian banks, supporting the theoretical explanation that a "main bank" often requires collateral to limit the borrowers' ability to obtain future loans from other lenders and reduce the risk of excessive future borrowing (Mann, 1997). No correlation between collateral and loan risk is found in Elsas and Krahnen (2000) who test the relationship between borrower quality and the incidence of collateral in top five German banks. They conclude that collateral is required primarily by lenders that have a previous relation with borrowers in order to lock borrowers in to the relation and therefore increase the bargaining power of banks in the future renegotiation. Cressy and Toivanen (2001) also find no evidence of significant relationship between default and collateral requirement for UK banks.

Berger et al. (2016) argues that contradictory empirical findings about the relationship between collateral pledging and loan risk arise from different data samples with different types and characteristics of collateral. Instead of comparing secured and 
unsecured loans, they investigate the effect of the underlying collateral characteristics on loan risk and find that liquid collateral is associated with especially low risk premium and that these loans perform better than those backed by illiquid collateral or no collateral. One part of their findings supports ex ante theories while the other part is consistent with ex post theories. Japhet and Memba (2015) examine the types of collateral which are preferred by banks in Kenya in order to reduce loan risk. They find that motor vehicles are preferred to land and buildings since the process of liquidating land and building usually involve complicated legal procedures and higher costs. This finding leads to a conclusion that the more liquid and desirable collateral is, the lower the loan's PD is. Some other papers analyze the effects of individual economic features and collateral types on loan rate premium (Benmelech \& Bergman, 2009, 2011; Benmelech, Garmaise, \& Moskowitz, 2005; John et al., 2003). The empirical results from those studies confirm that collateral characteristics have different risk implications for different types of borrowers.

Overall, the literature on the economic function of collateral on default risk is extensive, however there are discrepancies in the empirical evidence given the differences in economic environment, bank behavior and especially collateral characteristics. Additionally, the empirical evidence comes primarily from studies in developed countries with limited research focus on emerging markets and transition economies due to data limitations. Also, a vast number of studies investigate this relationship for commercial loans while ignoring consumer loans. One reason is that information about individual borrowers is almost impossible to obtain. However, it is argued that consumer loans suffer more serious problem of information asymmetry that induces banks to require collateral as the first and most important factor in determining whether or not loan applications are accepted. 
In an effort to seek more robust evidence from a transition economy with a collateral-based lending environment, this study uses a unique dataset of 2,295 consumer loan accounts from Vietnam to answer the following research questions:

To what extent, does the collateral quality affect a loan's default risk, and hence banks' lending decisions?

How do empirical estimates of the collateral effect on loan risk relate the theoretical assumptions about the specific transmission mechanism?

\section{Collateral-Based Lending in Vietnam}

In Vietnam, the presence of severe information asymmetry, weak credit information system, poor risk management, and underdeveloped financial infrastructure has resulted in a heavy reliance on collateral in bank lending. Collateral becomes an essential factor that affects lending decisions by Vietnamese banks, especially for loans provided to households and individuals (Figure 1). Like other transition economies, the banking sector recently shifted their lending to enterprises to collateralized lending to households, which accounts for much of the growth in credit (Bonin, Hasan, \& Wachtel, 2014). Good collateral is believed to be a mitigating factor to deal with the problems of adverse selection and moral hazard (Menkhoff et al., 2006) and help to increase access to credit (Alvarez de la Campa, 2011). During the reform process, the Vietnamese government has been undertaking strong effort to improve the credit environment and facilitate collateral-based lending. The promulgation of the 2005 Civil Code and Decree 163-2006/ND-CP was a significant step to promote secured transactions and asset-based lending in line with international practices. This legal framework allows all kinds of assets (i.e. immovable and movable assets, tangible and intangible assets) to be used as collateral and gives secured-creditors the right to seize 
or sell collateral privately (not through an auction) when the debtor defaults. The collateral-registry system has also been upgraded and computerized.

However, secured credit granted against movable assets is still limited in Vietnam although there has been a substantial increase since the launch of new centralized online registry for movable assets in 2012. The lack of knowledge and experience on movable asset-based lending, adequate legal framework and effective asset monitoring is considered to be main obstacles. This problem has not only existed in the credit environment of Vietnam but also in many developing countries according to the World Bank. Lending in Vietnam is biased toward real estate, the most preferable collateral by commercial banks. The continuing real estate fever contributes to increases in this desirable type of asset. Although the price of housing has been soaring to almost unbelievable heights year by year, there is always substantial demand for real estate, especially in big and crowed cities of HCM and Hanoi.

Figure 1 - Factors for Making Lending Decisions by Banks

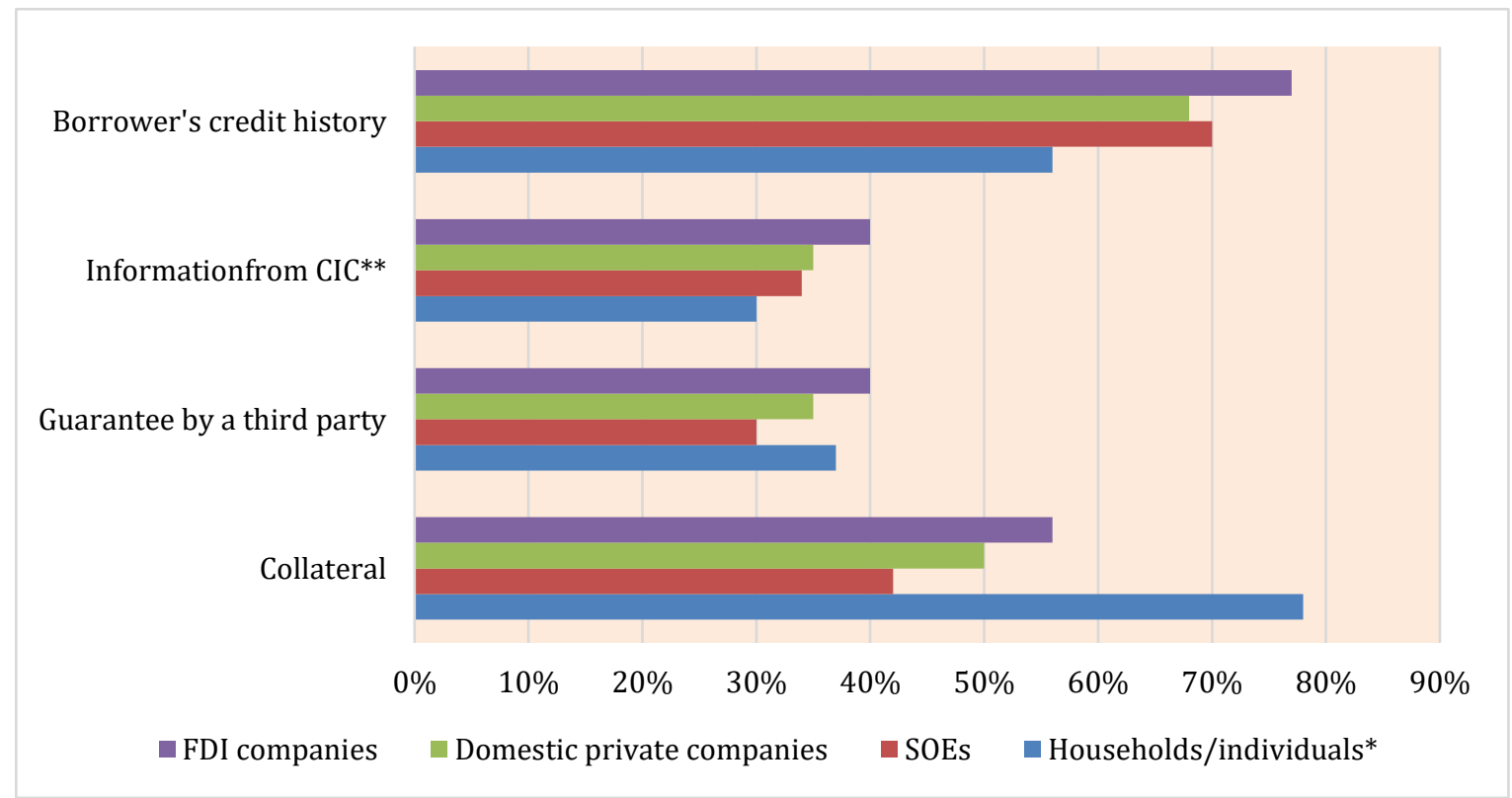

Notes: $\left(^{*}\right)$ Including mini-companies, ${ }^{* *}$ ) CIC represents Credit Information Center

Source: IFC-VBA Financial Sector Survey in "Vietnam Increasing Access to Credit Through Collateral (Secured Transactions Reform)” 
Figure 2 - Types of Assets Preferred as Collateral by Banks in Vietnam

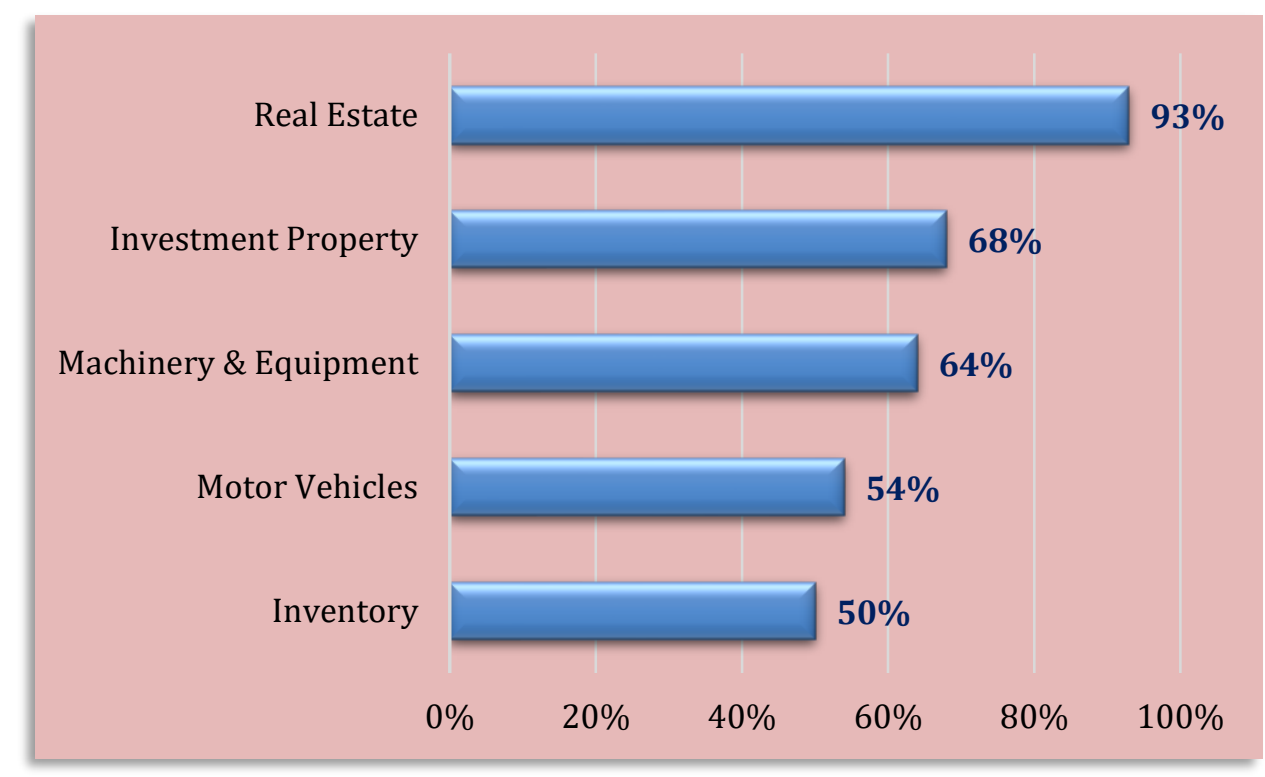

Source: IFC-VBA Financial Sector Survey in "Vietnam Increasing Access to Credit Through Collateral (Secured Transactions Reform)"

Figure 2 provides statistics of top five assets used as collateral by commercial banks for all loan types in Vietnam from WB-IFC and Vietnam Bankers Association's financial sector survey of lending practice in Vietnam (IFC-VBA Financial Sector Survey) ${ }^{1}$. Questionnaires were sent to 89 bank and non-bank financial institutions in Vietnam. The result reveals a strong preference toward real estate since this type of asset was selected as the most preferred collateral by $93 \%$ of surveyed financial institutions followed by machinery and equipment, chosen by more than $60 \%$ of financial institutions. While machinery and equipment are the most preferred movable assets as collateral, securities are among the least desirable collateral with the lowest quality ranking. Unlike developed markets where securities are considered one of the most liquid assets, Vietnamese commercial banks are more cautions and reluctant to accept securities since the stock

\footnotetext{
1 This is a part of a project conducted by IFC's Mekong Private Sector Development Facility (MPDF), the Investment Climate Advisory Service (FIAS) in association with the Vietnam Bankers' Association in 2006. The survey captures baseline data regarding private sector lending practices in order to measure and monitor the legal reforms' progress and impact. The report was published in "Vietnam - Increasing Access to Credit through Collateral (Secured Transactions Reform)".
} 
market is still in the early stage of development. Some big banks have recently offered stock-collateralized loans but the loan volume has not exceeded 50\% of the stocks' market value. In many cases, movable assets are accepted as a supplementary collateral when the value of the primary collateral (generally real estate) is not sufficient.

Pledging collateral does not necessarily require transfer of possession but there is collateral registry maintained by government agencies. Under the document registration system, a debtor has to sign a written-agreement about the use of assets as collateral and the associated secured obligation. However, upon default by the borrower, the real property foreclosure process is burdensome and time-consuming. The absence of clarity in the country's laws on collateral repossession is another obstacle. The procedure for banks to exercise the rights to sell or dispose of collateralized property is controlled by court judgments. Therefore, loss mitigation from collateral recovery is still questionable.

\section{Methodology and Data}

We examine the effect of the collateral quality on the PD of individual loans using data from 2,295 credit files collected from the internal loan accounts of a commercial bank in Vietnam². The filtering process for data from individual loan accounts is based on the following criteria: (i) loans were first initiated in the years 2010, 2011, 2012 and matured before 03/31/2016; (ii) loans have short and medium terms (from 12 to 60 months); (iii) loan amount is at least VND 100 million (about USD 4,500); (iv) each loan account is secured by only one asset and this asset is used as a collateral for that loan account at each point of time; (v) locations where loans are applied and approved are Hanoi and HCMC, the two biggest and most important cities of administration and business in Vietnam.

\footnotetext{
2 This type of data is highly confidential so the scope of this study is narrow but this unique data set helps avoid heterogeneous effects among banks.
} 
In this sample, collateral quality is ranked based on the bank's internal policy on collateral classification and ranking which is based on the collateral type, its desirability to the lender and discounted risk level of collateral value. Collateral is relatively diversified in terms of types, for example: (i) deposits, account balance, papers issued by financial institutions, (ii) residential real-estates, (iii) agricultural land, (iv) factory and warehouse, (v) transportation vehicles, (vi) machinery \& equipment, (vii) securities (bonds and stocks)... Sub-classification among these collateral types is even more diversified and complicated as it also depends on liquidity level and underlying discounted risks. Assets of the same type are not always categorized in the same group and rank. For example, residential real-estate is classified based on its location with most desirable or highest rank assigned to urban frontage houses and residential land located in the center of HCMC or Hanoi. Residential real-estates are downgraded to lower levels if they are suburban houses/land and/or located in the alley or far from the city infrastructure or in other provinces. Transportation vehicles are also classified and raked based on their brand names, number of years in use, size and function categories. In other words, sub-classification in one asset type is more likely driven by its liquidity.

This paper follows Berger et al. (2016), applying Probit regression model to examine the effect of the collateral's quality level on the PD of individual loans. In theory, a borrower will default if the utility that he/she expects to obtain when default is greater than not default. Call $\mathrm{y}^{*}$ it is the difference in the utility mentioned above and $\mathrm{y}^{*}{ }_{\text {it }}$ is nonobservable. A borrower will default if $y^{*}{ }_{i t}>0$, suggesting that borrower get higher utility in case of default.

The empirical model is then developed as follows:

$$
y_{i t}^{*}=\alpha+x_{i t}^{\prime} \beta+z_{i t}^{\prime} \gamma+w_{i t}^{\prime} \Omega+\varepsilon_{i t}(1)
$$

where: 
$y_{i t}$ is default decision of borrower $i$ who get a loan in year $t, y_{i t}$ is an endogenous variable and dichotomous, such that $y_{i t}=\left\{\begin{array}{l}1, y_{i t}^{*} \geq 0 \\ 0, y_{i t}^{*}<0\end{array}\right.$, for $i=1.2 \ldots . n$. In this study, dependent variable $y_{i t}$ is a proxy for loan risk or ex post nonperformance which takes the value of 1 if loan $i$ generated in year $t$ is in default and 0 otherwise. A loan is in default if it is downgraded to the rank 3-5 or is overdue more than 90 days during the loan term according to 493/2005/QĐ-NHNN, and 18/2007/QĐ-NHNN regulations that were promulgated by $\mathrm{SBV}^{3}$;

$x^{\prime}{ }_{i t}$ are variables representing collateral characteristics including collateral ranks based on quality levels, coverage ratio and ownership status. Collateral quality is decided based on the internal rating policy of bank. Our sample consists of six rating classes, ranking from 1 to 6 . The highest rank is 6, representing the most preferential or highest quality collateral while the lowest rank of 1 includes least desirable collateral. Coverage ratio is measured by the ratio between collateral value and loan volume, implying the protected level of loan. In another words, we concern the level of coverage that collateral provides for the loan. The ownership status is a dummy variable which takes the value of 1 if the collateral is owned by the borrower and 0 otherwise 4 .

$z^{\prime}{ }_{i t}$ is a set of variables of loan characteristics including loan term, loan size (volume), and interest rate;

$w^{\prime} t$ is a vector of control variables for borrower characteristics such as borrower's profession, borrowing purposes and regional factors;

$\varepsilon_{i t}$ is the error term;

\footnotetext{
3 These documents regulated the debt classification and provision that applied for financial institutions in Vietnam.

${ }^{4}$ Banks also accept the collateral which is owned by borrower's family members, e.g. spouse, mother, farther, children, brothers/sisters.
} 
It is widely addressed in the literature that loan contract terms (loan size, maturity, interest rate, collateral...) are endogenous and jointly determined by borrower characteristics and lending policies (laut, 1985). In this case, the correlation between the regressors and the error term is not zero $\left(E\left(z^{\prime}, \varepsilon\right) \neq 0\right)$, so that the probit model estimation can be biased because of endogeneity. To address this issue, we estimate the endogenous probit model using instrumental variables (instrument variable probit, IVP) proposed by (Newey, 1987 1990). We assume that loan characteristics (size, interest rate, maturity) are endogenous regressors and instrumental variables include borrowers' characteristics, borrowing purposes, collateral and potential difference in lending policies from year to year.

Interpreting the magnitudes of probit coefficients is not straightforward, because it depends on the slope of the cumulative distribution function (CDF). We, therefore compute the average marginal effects of explanatory variables on the probabilities, i.e. the changes in the response probabilities as a result of one-unit change in the explanatory variables. These marginal effects (ME) are calculated as:

$$
M E=\operatorname{Prob}\left(y=1 \mid x, x_{k}=1\right)-\operatorname{Pr}\left(y=1 \mid x, x_{k}=0\right)
$$

The definitions of variables are presented in Table 1 while Table 2 describes the distribution of loan delinquency (PD) according to each explanatory variable. Accordingly, most collateral in sample belong to rank 5 with 1,166 observations, or $50.81 \%$ of the loan accounts. The default rate is high $(>30 \%)$ for ranks $1-3$ but declines with increasing quality level. In order to have more insight regarding the distribution of the coverage ratio, we classify the sample into three categories. Cover1 represents the highest coverage level in which loan volume is less than $50 \%$ of collateral value. Cover2 consists of loans which have volume from $50-75 \%$ of collateral value while Cover3 includes loans with volume higher than $75 \%$ of collateral value. But the statistics appear 
to be ambiguous as default rate is highest in Cover1 (extremely high value of collaterals) but significantly drops in Cover2 and slightly increases in Cover3. Table 2 also shows that bigger loan size and highly protected loan are riskier. Also, borrowers of short-term loan have higher PD.

Table 1 - Definition of variables

\section{Variables Definitions}

\section{Dependent variables ( $\left.y_{i t}\right)$}

Default risk Dummy variable takes the value of 1 if a loan is downgraded to the (Loan's PD) level of 3 - 5 or loan is overdue more than 90 days, and 0 otherwise

\section{Collateral characteristics $\left(x_{i t}^{\prime}\right)$}

Corank1-6 Collateral quality is a categorical variable proxied by a series of dummies representing six ranking classes (1 to 6) according to bank's internal ranking policy.

Coverage Coverage ratio is measured by the ratio between collateral value and loan volume, implying the protected level of loan.

Ownership Dummy variable takes the value of 1 if collateral is owned by borrower and 0 if it owned by borrower's family members.

\section{Loan characteristics $\left(z_{i t}^{\prime}\right)$}

Loanterm Number of months between loan origination and maturity

Loansize Loan size is calculated by the natural logarithm of loan volume.

Interest Average interest rate of loans per 3 months during loan term (\%).

\section{Control variables (wit)}

Profession Three dummy variables are constructed to represent three different groups of borrowers' professions: Trade, Service and Nonbusiness. Borrowers classified in Nonbusiness group are workers, employees in government agencies and companies.

Purpose $\quad$ Four dummy variables are constructed represent different purposes of lending from borrowers, such that:

- Pconsum: borrowing for consumption purpose

- Pestate: borrowing to buy residential house or flat

- Pbusiness: borrowing for working capital supplement in private business of borrower

- Pother: other purposes such as investment

Location(HCM) The dummy variable takes the value of 1 if loan was applied and 
generated in HCMC and 0 if it was in Hanoi.

Year

Time (dummy variables) when loan was originated. This is to control for the difference in lending policies from year to year

Table 2 - The distribution of the sample

\begin{tabular}{|c|c|c|c|c|}
\hline \multirow{2}{*}{ Collateral rank } & \multicolumn{2}{|r|}{ Default } & \multirow{2}{*}{ No. of loans } & \multirow{2}{*}{$\begin{array}{r}\text { Default } \\
\text { rate }\end{array}$} \\
\hline & $\mathbf{0}$ & 1 & & \\
\hline Colrank1 & 37 & 20 & 57 & 0.35 \\
\hline 2 & 70 & 45 & 115 & 0.39 \\
\hline 3 & 288 & 141 & 429 & 0.33 \\
\hline 4 & 278 & 62 & 340 & 0.18 \\
\hline 5 & 1,021 & 145 & 1,166 & 0.12 \\
\hline 6 & 162 & 26 & 188 & 0.14 \\
\hline \multicolumn{5}{|l|}{ Coverage } \\
\hline Cover1 & 1,011 & 313 & 1,324 & 0.24 \\
\hline Cover2 & 506 & 55 & 561 & 0.10 \\
\hline Cover3 & 163 & 37 & 200 & 0.19 \\
\hline \multicolumn{5}{|l|}{ Loanterm (months) } \\
\hline 12 & 1,011 & 313 & 1,324 & 0.24 \\
\hline 36 & 506 & 55 & 561 & 0.10 \\
\hline 48 & 163 & 37 & 200 & 0.19 \\
\hline 60 & 176 & 34 & 210 & 0.16 \\
\hline \multicolumn{5}{|l|}{ Loansize (mil. VND) } \\
\hline Size $1 \leq 500$ & 1,211 & 159 & 1,370 & 0.12 \\
\hline Size2: $500-1,000$ & 401 & 103 & 504 & 0.20 \\
\hline Size $3>1,000$ & 244 & 177 & 421 & 0.42 \\
\hline
\end{tabular}

Descriptive statistics of collateral quality, loan size, loan term, and interest rate are summarized in Table 3 which shows the wide heterogeneity in the data sample. The mean of collateral preference is 4.3 which show the dominance of quality ranks of 4 - 6 (highly desirable and qualified assets). The coverage ratio ranges from 1 to 65 , implying that all loans are fully secured by collateral value. The loan interest rate varies from $16 \%$ to $26 \%$. Loan volumes less than VND 1 bil. dominates the sample with its mean value of VND 678,7 million (USD 30,850 approximately). The majority of loans in the sample are short-term loans (1 year). Seventy percent of loans are in HCMC and the loan purpose is mainly for business (more than 50\%). 
Table 3 - Descriptive statistics of collateral and loan characteristics

\begin{tabular}{lcccc}
\hline Variable & Mean & Std. Dev. & Min & Max \\
\hline $\begin{array}{l}\text { Colrank1-6 } \\
\text { Coverage }\end{array}$ & 4.310 & 1.162 & 1 & 6 \\
$\begin{array}{l}\text { Loansize } \\
\text { (VND mil.) }\end{array}$ & 2.891 & 3.395 & 1.082 & 65.8 \\
$\begin{array}{l}\text { Loanterm } \\
\text { (months) }\end{array}$ & 678.717 & 841.605 & 100 & 30,000 \\
Interest & 25.396 & 16.89 & 12 & 60 \\
Location & 0.219 & 0.031 & 0.16 & 0.26 \\
Pbusiness & 0.715 & 0.452 & 0 & 1 \\
Pconsum & 0.553 & 0.497 & 0 & 1 \\
Pestate & 0.228 & 0.419 & 0 & 1 \\
Pother & 0.107 & 0.309 & 0 & 1 \\
\hline
\end{tabular}

\section{Empirical Results}

We run three estimations of the IVP model (1 - 3) and report the full information of regression output in Table 4. In each regression, we include each of loan characteristic variable to avoid the problem of multicollinearity. The set of instruments includes variables representing collateral, borrowers' characteristics and difference in loan policies from year to year (time dummies). These factors are assumed to endogenously affect loan contract terms (interest, loan size and maturity). The maximum likelihood estimation results show that our variables of interest, collateral quality (rank 4-6) and coverage ratio, are statistically significant at the confidence level of $95 \%$ and $99 \%$ respectively, supporting the hypothesis that collateral characteristics can explain the variation in loan default risk of the investigated bank. The negative sign of coefficients on these variables suggest that loan secured by more desirable collateral has lower risk. 
Table 4 - IVP regression on loan's PD

\begin{tabular}{|c|c|c|c|}
\hline Variables & (1) & (2) & (3) \\
\hline \multicolumn{4}{|c|}{ Colateral characterstics } \\
\hline \multicolumn{4}{|l|}{ Colrank } \\
\hline \multirow[t]{2}{*}{2} & -0.219 & -0.215 & -0.228 \\
\hline & $(0.218)$ & $(0.218)$ & $(0.228)$ \\
\hline \multirow[t]{2}{*}{3} & $-0.323^{*}$ & -0.302 & -0.322 \\
\hline & $(0.191)$ & $(0.192)$ & $(0.201)$ \\
\hline \multirow[t]{2}{*}{4} & $-0.469 * *$ & $-0.480^{* *}$ & $-0.509^{* *}$ \\
\hline & $(0.196)$ & $(0.197)$ & $(0.204)$ \\
\hline \multirow[t]{2}{*}{5} & $-0.721^{* * *}$ & $-0.698^{* * *}$ & $-0.754^{* * *}$ \\
\hline & $(0.185)$ & $(0.185)$ & $(0.194)$ \\
\hline \multirow[t]{2}{*}{6} & $-0.488^{* *}$ & $-0.483^{* *}$ & $-0.647^{* * *}$ \\
\hline & $(0.216)$ & $(0.217)$ & $(0.239)$ \\
\hline \multirow[t]{2}{*}{ Coverage } & $-0.069 * * *$ & $-0.070^{* * *}$ & $-0.044^{* * *}$ \\
\hline & $(0.015)$ & $(0.015)$ & $(0.017)$ \\
\hline \multirow{2}{*}{ Ownership } & 0.082 & 0.099 & 0.086 \\
\hline & $(0.092)$ & $(0.093)$ & $(0.093)$ \\
\hline \multicolumn{4}{|c|}{ Loan characteristics } \\
\hline \multirow[t]{2}{*}{ Interest } & 0.673 & & \\
\hline & $(1.250)$ & & \\
\hline \multirow[t]{2}{*}{ Loanterm } & & -0.005 & \\
\hline & & $(0.003)$ & \\
\hline \multirow[t]{2}{*}{ Loansize } & & & 0.471 \\
\hline & & & $(0.338)$ \\
\hline \multicolumn{4}{|l|}{ Control variables } \\
\hline \multirow[t]{2}{*}{ Nonbusiness } & $-0.609 * * *$ & $-0.488^{* * *}$ & $-0.464^{* * *}$ \\
\hline & $(0.073)$ & $(0.104)$ & $(0.114)$ \\
\hline \multirow[t]{2}{*}{ Service } & $-0.424^{* * *}$ & $-0.378^{* * *}$ & $-0.352^{* * *}$ \\
\hline & $(0.095)$ & $(0.098)$ & $(0.116)$ \\
\hline \multirow[t]{2}{*}{ Location(HCM) } & $-0.760 * * *$ & $-0.791^{* * *}$ & $-0.702^{* * *}$ \\
\hline & $(0.076)$ & $(0.075)$ & $(0.089)$ \\
\hline \multirow[t]{2}{*}{ Constant } & 0.495 & $0.716^{* * *}$ & -0.799 \\
\hline & $(0.338)$ & $(0.203)$ & $(1.045)$ \\
\hline Log likelihood & 6409.39 & -9130.44 & -1181.87 \\
\hline Wald chi2 & 290.940 & 292.27 & 271.42 \\
\hline Prob. & 0.000 & 0.000 & 0.000 \\
\hline
\end{tabular}

Notes: Standard errors are in parentheses. ${ }^{* * *},{ }^{* *}$, and ${ }^{*}$ denote significance at $1 \%, 5 \%$ and $10 \%$, respectively. 


\begin{tabular}{|c|c|c|c|c|c|c|}
\hline $\begin{array}{l}\text { Variables } \\
\text { Colrank }\end{array}$ & \multicolumn{2}{|c|}{ (1) } & \multicolumn{2}{|c|}{ (2) } & \multicolumn{2}{|c|}{ (3) } \\
\hline 2 & -0.068 & $(0.069)$ & -0.069 & $(0.069)$ & -0.050 & $(0.071)$ \\
\hline 3 & -0.098 & $(0.061)$ & -0.096 & $(0.061)$ & -0.081 & $(0.063)$ \\
\hline 4 & $-0.137^{* *}$ & $(0.062)$ & $-0.142^{* *}$ & $(0.062)$ & $-0.131^{* *}$ & $(0.062)$ \\
\hline 5 & $-0.195^{* * *}$ & $(0.059)$ & $-0.193^{* * *}$ & $(0.059)$ & $-0.196^{* * *}$ & $(0.060)$ \\
\hline 6 & $-0.142^{* *}$ & $(0.066)$ & $-0.143^{* * *}$ & $(0.066)$ & $-0.199 * * *$ & $(0.065)$ \\
\hline Coverage & $-0.016^{* * *}$ & $(0.003)$ & $-0.016^{* * *}$ & $(0.003)$ & -0.006 & $(0.003)$ \\
\hline Ownership & 0.019 & $(0.021)$ & 0.022 & $(0.021)$ & 0.019 & 0.020 ) \\
\hline Interest & 0.200 & $(0.292)$ & & & & \\
\hline Loanterm & & & -0.001 & $(0.001)$ & & \\
\hline Loansize & & & & & $0.257^{* * *}$ & $(0.070)$ \\
\hline Nonbusiness & $-0.142^{* * *}$ & $(0.016)$ & $-0.115^{* * *}$ & $(0.024)$ & $-0.093^{* * *}$ & $(0.027)$ \\
\hline Service & $-0.099^{* * *}$ & $(0.022)$ & $-0.090^{* * *}$ & $(0.022)$ & $-0.056^{* *}$ & $(0.026)$ \\
\hline Location(HCM) & $-0.178^{* * *}$ & $(0.016)$ & $-0.184^{* * *}$ & $(0.017)$ & $-0.127^{* * *}$ & $(0.021)$ \\
\hline Pconsum & .0001 & $(0.000)$ & $0.002^{* * *}$ & $(0.001)$ & $0.018^{* * *}$ & $(0.003)$ \\
\hline Pbusiness & $.0003^{* * *}$ & $(0.000)$ & $0.017^{* * *}$ & $(0.001)$ & $-0.028^{* * *}$ & $(0.003)$ \\
\hline Pestate & $.0001^{* * *}$ & $(0.000)$ & -0.001 & $(0.001)$ & -0.005 & $(0.003)$ \\
\hline Year2011 & -.0001 & $(0.000)$ & $0.008^{* * *}$ & $(0.000)$ & $-0.011^{* * *}$ & $(0.002)$ \\
\hline Year2012 & $0.003^{* * *}$ & $(0.000)$ & $0.008^{* * *}$ & $(0.000)$ & $-0.013^{* * *}$ & $(0.003)$ \\
\hline
\end{tabular}

Note: Probability of positive outcome, dy/dx for factor levels is the discrete change from the base level. Standard errors are in parentheses. ${ }^{* * *}$ and ${ }^{* *}$ denote significance at $1 \%$ and $5 \%$, respectively.

The calculation of average marginal effect presented in Table 5 reveals that collateral belonging to rating class of 4-6 helps to reduce a loan's PD from 1.31 to 1.99 percent point comparing to collateral in rating 1 , ceteris paribus. However, there is no significant difference on the PD of loan secured by collateral ranked from 1 to 3 . Additionally, 1 percent increase in coverage ratio may lead to a drop in PD by $0.6-1.6$ basis point. This finding is relatively consistent with that of Berger et al. (2016) for the case of Bolivia and supports the dominance of borrower selection and risk-shifting over lender selection effects. Accordingly, borrowers who pledge more desirable and higher 
value collateral are more careful to select investment projects and exert efforts in using bank loan efficiently to prevent asset loss in the case of default. In other words, they have less incentive to default than ones who pledge with less desirable collateral. Furthermore, wealthier borrowers are more likely to pledge valuable assets as collateral to obtain better terms in loan contract; they therefore have better capacity for loan repayment. This finding is inconsistent with the theoretical explanation in Stiglitz and Weiss (1981) that wealthy borrowers are those who have succeeded at risky endeavors, then the riskiness of loans may increase if they are protected by collateral with higher value. Since our data sample does not include bad debt recovery from collateral liquidation, there is no evidence regarding the loss mitigation effect.

Beside collateral quality, credit risk is significantly driven by borrowers' profession and regional factor. The coefficient on profession variables indicate that borrowers who own their business are riskier than employees in government agencies and companies because their income are more stable and less affected by the business cycle. In term of regional effects, we find that loan's PD in HCMC is significantly lower than that of Hanoi. However, the effects of loan characteristic variables appear to be insignificant in all estimation. This finding seems to be inconsistent with existing literature (ఏiménez \& Saurina, 2004; Stiglitz \& Weiss, 1981) but reflects the poor lending practice in Vietnam that loan contract terms have been not optimally designed and that credit evaluation and risk management play no significant role in lending decisions.

\section{Conclusions and Policy Implications}

Motivated by Berger et al. (2016)'s explanation for the conflicting results of the collateral-risk relation in the literature, this study investigates the impact of collateral characteristics on loan default probability and transmission channels of this effect at the commercial banks in Vietnam. We use the IVP analysis on pooled data of 2,295 
individual credit files to seek answers for two research questions: (i) To what extent, does the collateral quality affect a loan's default risk, and hence banks' lending decisions? and (ii) How do empirical estimates of the collateral effect on loan risk relate the theoretical assumptions about the specific transmission mechanism? For the first questions, we find that collateral of high quality helps to reduce the PD of a loan. Specifically, default risk is likely to be heterogeneous within rating classes of collateral such that highly desirable collateral not only signals more credible borrower but also fosters good behavior in investment behaviour, enabling bank to mitigate adverse selection and moral hazard problems. The empirical results also answer our second question regarding the transmission channels, confirming the dominance of borrower selection and risk-shifting over lender selection effects of collateral for the case of Vietnam. Moreover, default risk is also dependent on borrower's profession and regional factor, suggesting important implication in customer and market targeting in developing credit strategies for commercia banks.

The findings from this paper may provide possible explanation for the collateralbased lending and borrower behavior in Vietnam, the market associated with serious information asymmetries as consequences of weak credit risk management, ineffective public records, restrictive and complicated regulatory environment and underdeveloped information infrastructure. The use of collateral not only increases households' access to credit and boost financial inclusion but it also generates strong risk-reducing incentives for borrower. Therefore, an adequate secured lending framework supported by effective collateral laws and registries is essential to improve lending environment. Despite SBV and government has undertaken strong efforts to create a sound legal and institutional infrastructure to maximize the economic potential of assets that can be used as collateral, the implementation has not been sufficiently effective. Reform should be 
conducted to provide clear rules on priority for the secured creditor and enforcement of security upon default.

However, heavy reliance on collateral may increase banks' appetite for risk-taking. As commercial banks in Vietnam have been increasingly providing mortgage loans which are proved to be prone to the swings in asset prices and increase the economic vulnerability. The period of 2010 - 2012 experienced an incredible increase in bad debts in Viet Nam as a consequence of falling housing price. This situation is similar to that of Thailand in 1997 and the US during 2007 - 2009, which has raised a big concern for SBV to develop monitoring and supervision mechanism to control subprime mortgage credit.

\section{Acknowledgements}

We would like to thank Professor Paul Wachtel and the anonymous reviewers for valuable comments and suggestions to earlier versions of our manuscript. Any remaining errors are entirely the authors' responsibility.

\section{References}

Alvarez de la Campa, A. (2011). Increasing access to credit through reforming secured transactions in the MENA region. Policy Research Working Paper; No. WPS 5613. World Bank.

Benmelech, E., \& Bergman, N. K. (2009). Collateral pricing. Journal of Financial Economics, 91(3), 339-360.

Benmelech, E., \& Bergman, N. K. (2011). Bankruptcy and the collateral channel. The Journal of Finance, 66(2), 337-378.

Benmelech, E., Garmaise, M. J., \& Moskowitz, T. J. (2005). Do liquidation values affect financial contracts? Evidence from commercial loan contracts and zoning regulation. The Quarterly Journal of Economics, 120(3), 1121-1154. 
Berger, A. N., Frame, W. S., \& Ioannidou, V. (2016). Reexamining the empirical relation between loan risk and collateral: The roles of collateral liquidity and types. Journal of Financial Intermediation, 26, 28-46.

Berger, A. N., \& Udell, G. F. (1990). Collateral, loan quality and bank risk. Journal of Monetary Economics, 25(1), 21-42.

Bester, H. (1985). Screening vs. rationing in credit markets with imperfect information. The American Economic Review, 75(4), 850-855.

Brick, I. E., \& Palia, D. (2007). Evidence of jointness in the terms of relationship lending. Journal of Financial Intermediation, 16(3), 452-476.

Cerqueiro, G., Ongena, S., \& Roszbach, K. (2016). Collateralization, bank loan rates, and monitoring. The Journal of Finance, 71(3), 1295-1322.

Cressy, R., \& Toivanen, O. (2001). Is there adverse selection in the credit market? Venture Capital: An International Journal of Entrepreneurial Finance, 3(3), 215-238.

Degryse, H., \& Van Cayseele, P. (2000). Relationship lending within a bank-based system: Evidence from European small business data. Journal of Financial Intermediation, $9(1), 90-109$.

Elsas, R., \& Krahnen, J. P. (2000). Collateral, default risk, and relationship lending: An empirical study on financial contracting. CFS Working Paper Series 1999/13, Center for Financial Studies (CFS).

Godlewski, C. J., \& Weill, L. (2011). Does collateral help mitigate adverse selection? A crosscountry analysis. Journal of Financial Services Research, 40(1-2), 49-78.

Haselmann, R., \& Wachtel, P. (2007). Risk taking by banks in the transition countries. Comparative Economic Studies, 49(3), 411-429. 
Japhet, B. O., \& Memba, F. (2015). Influence of collaterals used by Small and Medium Microenterprises on loan performance of commercial banks in Kisii county, Kenya. International Journal of Economics, Commerce and Management, 11(3), 889-900.

Jiménez, G., \& Saurina, J. (2004). Collateral, type of lender and relationship banking as determinants of credit risk. Journal of Banking \& Finance, 28(9), 2191-2212.

John, K., Lynch, A. W., \& Puri, M. (2003). Credit ratings, collateral, and loan characteristics: Implications for yield. The Journal of Business, 76(3), 371-409.

Machauer, A., \& Weber, M. (1998). Bank behavior based on internal credit ratings of borrowers. Journal of Banking \& Finance, 22(10), 1355-1383.

Mann, R. J. (1997). The role of secured credit in small-business lending. Georgetown Law Journal, 86, 1. Available at SSRN: $\underline{\text { https://ssrn.com/abstract=564641 }}$

Menkhoff, L., Neuberger, D., \& Suwanaporn, C. (2006). Collateral-based lending in emerging markets: Evidence from Thailand. Journal of Banking \& Finance, 30(1), 1-21.

Newey, W. K. (1987). Efficient estimation of limited dependent variable models with endogenous explanatory variables. Journal of Econometrics, 36(3), 231-250.

Newey, W. K. (1990). Efficient instrumental variables estimation of nonlinear models. Econometrica: Journal of the Econometric Society, 58(4), 809-837.

Pagano, M., Manove, M., \& Padilla, J. (2001). Collateral vs. Project Screening: A Model of Lazy Banks. The RAND Journal of Economics, 32(4), 726-744.

Plaut, S. E. (1985). The theory of collateral. Journal of Banking \& Finance, 9(3), 401-419.

Stiglitz, J. E., \& Weiss, A. (1981). Credit rationing in markets with imperfect information. The American Economic Review, 71(3), 393-410. 
Voordeckers, W., \& Steijvers, T. (2006). Business collateral and personal commitments in SME lending. Journal of Banking \& Finance, 30(11), 3067-3086.

Bonin, J., Hasan, I., \& Wachtel, P. (2014). Banking in transition countries. BOFIT Discussion Paper No. 8/2014. 